\title{
Phytoextraction of Lead Using a Hedge Plant [Alternanthera bettzickiana (Regel) G. Nicholson]: Physiological and Biochemical Alterations through Bioresource Management
}

\author{
Urooj Kanwal ${ }^{1}$, Muhammad Ibrahim ${ }^{1, *}$, Farhat Abbas ${ }^{2}{ }^{\mathbb{D}}$, Muhammad Yamin ${ }^{3} \mathbb{D}$, Fariha Jabeen ${ }^{1}$, \\ Anam Shahzadi ${ }^{4}$, Aitazaz A. Farooque ${ }^{2, *}$, Muhammad Imtiaz ${ }^{5}$, Allah Ditta ${ }^{6,7}$ ) and Shafaqat Ali ${ }^{1}$ \\ 1 Department of Environmental Sciences \& Engineering, Government College University Faisalabad, \\ Faisalabad 38000, Pakistan; uroojkanwal555@yahoo.com (U.K.); fariha.jabeen88@gmail.com (F.J.); \\ shafaqataligill@yahoo.com (S.A.) \\ 2 School of Climate Change and Adaptation, University of Prince Edward Island, Charlottetown, PE C1A 4P3, \\ Canada; fabbas@upei.ca \\ 3 Department of Farm Machinery \& Power, Faculty of Agricultural Engineering \& Technology, \\ University of Agriculture, Faisalabad, Faisalabad 38000, Pakistan; yamin529@uaf.edu.pk \\ 4 Department of Zoology, Wildlife and Fisheries, University of Agriculture, Faisalabad, Faisalabad 38000, \\ Pakistan; shahzadianam143@gmail.com \\ 5 Environmental Biotechnology Division, National Institute of Biotechnology \& Genetic Engineering (NIBGE), \\ Faisalabad 44000, Pakistan; m.imtiazpk92@hotmail.com \\ check for \\ updates \\ Citation: Kanwal, U.; Ibrahim, M.; \\ Abbas, F.; Yamin, M.; Jabeen, F.; \\ 6 Department of Environmental Sciences, Shaheed Benazir Bhutto University Sheringal, Upper Dir, \\ Khyber Pakhtunkhwa 18000, Pakistan; allah.ditta@sbbu.edu.pk \\ 7 School of Biological Sciences, the University of Western Australia, Perth, WA 6009, Australia \\ * Correspondence: ebrahem.m@gmail.com (M.I.); afarooque@upei.ca (A.A.F.); Tel.: +92-322-6037045 (M.I.)
} Shahzadi, A.; Farooque, A.A.; Imtiaz, M.; Ditta, A.; Ali, S. Phytoextraction of Lead Using a Hedge Plant [Alternanthera bettzickiana (Regel) G. Nicholson]: Physiological and Biochemical Alterations through Bioresource Management. Sustainability 2021, 13, 5074 https://doi.org/10.3390/ su13095074

Academic Editor: Imre J. Holb

Received: 8 March 2021

Accepted: 27 April 2021

Published: 30 April 2021

Publisher's Note: MDPI stays neutral with regard to jurisdictional claims in published maps and institutional affiliations.

Copyright: (c) 2021 by the authors. Licensee MDPI, Basel, Switzerland. This article is an open access article distributed under the terms and conditions of the Creative Commons Attribution (CC BY) license (https:// creativecommons.org/licenses/by/ $4.0 /)$.

Abstract: Phytoremediation is a cost-effective and environmentally friendly approach that can be used for the remediation of metals in polluted soil. This study used a hedge plant-calico (Alternanthera bettzickiana (Regel) G. Nicholson) to determine the role of citric acid in lead ( $\mathrm{Pb}$ ) phytoremediation by exposing it to different concentrations of $\mathrm{Pb}\left(0,200,500\right.$, and $\left.1000 \mathrm{mg} \mathrm{kg}^{-1}\right)$ as well as in a combination with citric acid concentration $(0,250,500 \mu \mathrm{M})$. The analysis of variance was applied on results for significant effects of the independent variables on the dependent variables using SPSS (ver10). According to the results, maximum $\mathrm{Pb}$ concentration was measured in the upper parts of the plant. An increase in dry weight biomass, plant growth parameters, and photosynthetic contents was observed with the increase of $\mathrm{Pb}$ application ( $200 \mathrm{mg} \mathrm{kg}^{-1}$ ) in soil while a reduced growth was experienced at higher $\mathrm{Pb}$ concentration (1000 $\mathrm{mg} \mathrm{kg}^{-1}$ ). The antioxidant enzymatic activities like superoxide dismutase (SOD) and peroxidase (POD) were enhanced under lower $\mathrm{Pb}$ concentration $\left(200,500 \mathrm{mg} \mathrm{kg}^{-1}\right)$, whereas the reduction occurred at greater metal concentration $\mathrm{Pb}\left(1000 \mathrm{mg} \mathrm{kg}^{-1}\right)$. There was a usual reduction in electrolyte leakage (EL) at lower Pb concentration (200, $500 \mathrm{mg} \mathrm{kg}^{-1}$ ), whereas EL increased at maximum $\mathrm{Pb}$ concentration (1000 $\mathrm{mg} \mathrm{kg}^{-1}$ ). We concluded that this hedge plant, A. Bettzickiana, has the greater ability to remediate polluted soils aided with citric acid application.

Keywords: lead; Alternanthera bettzickiana; citric acid; phytoremediation; antioxidants

\section{Introduction}

Industrial and anthropogenic deeds have led to an augmented proclamation of numerous heavy metals, including lead $(\mathrm{Pb})$ persistence in the environment for a long duration, which is why $\mathrm{Pb}$ is considered one of the most lethal pollutants [1]. Lead is released in the environment from diverse anthropogenic activities like electric batteries, burning of coal, gasoline, metallurgical, and paint explosives activities [2]. Whereas the amount of $\mathrm{Pb}$ released in the environment is comparatively more than natural release. Nearly 333 times more amount of $\mathrm{Pb}$ is released by human activities than natural discharge [3]. Ecological accomplishments such as windblown dust, forest fires, volcanic eruption, and sedimentary 
rocks are classified as regular causes of $\mathrm{Pb}$ contamination in soil. Lead contamination has become a worldwide issue due to its diligence in the environment and the toxicological concerns for wildlife, plants, and human populations [4]. Both types of activities, natural and anthropogenic, such as disposal from municipal sewage sludge, mining practices, fertilizers application, industrial fumes, storage batteries, forest fires, volcanic eruption, smelting of ores, paints, igneous rocks, gasoline, and explosives are the most important contributors of $\mathrm{Pb}$ in the environment [5]. Inorganic $\mathrm{Pb}$ cannot be degraded even at lower concentration and it is also collected from cultivated soils because different plant organs take it up. However, $\mathrm{Pb}$ entered the food chain through marine species while sea animals' uptake $\mathrm{Pb}$ from wastewater and accumulate in their body. As a result, consumers are at a high level of health risk [6].

The toxicity of $\mathrm{Pb}$ enhances the harmful impacts on plants; affects the defense system and photosynthesis [7]. Antioxidant enzymes like peroxidase (POD), superoxide dismutase (SOD), catalase (CAT), and ascorbate peroxidase (APX) considerably improved cellular redox homeostasis at a better point under $\mathrm{Pb}$ stress [8]. This is because the toxicity of lead overproduction of ROS agitates the redox equilibrium [7,9]. The phytoremediation process is the most important for contaminated soil through which many plants can uptake metals and detoxify the pollutants [10,11]. Green plants are used in phytoremediation and their related microorganisms to eradicate environmental impurities that make them inoffensive [12]. These plant-based techniques are used to improve environmental clean-up [13,14]. As associated with outdated physicochemical techniques, like chemical leaching or soil removal, which are costly and cause deleterious ecological effects, the phytoremediation method is possibly effective, cheap, also eco-friendly for renovating contaminated soils. This technology is less expensive rather than most in situ traditional processes [15]. In this technique, metal ions, immersion takes place by plant roots and later move to plant shoots, monitored by shoot yield also discarding [16].

Hence, hyperaccumulator plants that have suitable features for particular soil pollutants are essential to virtually relate phytoremediation techniques. The Alternanthera. bettzickiana plant was selected for the present study. In tropical America, A. Bettzickiana, also known as the calico plant, is a low statured inhabitant plant that is famous for its cultivation as a hedge/border plant $[17,18]$. It is an annual, ground cover, tender, and tropical perpetual herb $15-30 \mathrm{~cm}$ in height. Its selection was based upon its elevated biomass production and capability to grow in different soil textures and $\mathrm{pH}$ levels. Furthermore, it is documented that the maximum salt tolerance of $A$. Bettzickiana is reflected by its physiological characteristics. Application of various inorganic and organic chelators, phytoextraction process potential, can be improved which enhances the mobility and availability of $\mathrm{Pb}$ [19]. Therefore, chelators also improved the micronutrient taken up by plants as part of their regular physiological actions, which are helpful to plants and also help them to grow with metal toxicity $[20,21]$.

Citric acid (CA) is a naturally occurring, easily biodegradable, and cost-effective low molecular weight organic acid, which can be used as an alternate to synthetic ethylenediaminetetraacetic acid (EDTA) and can greatly enhance metal solubility in the solution medium and subsequent uptake by plant tissues [22-24]. The efficacy of CA for assisting metal ions uptake by plant roots and enhancing the translocation to aboveground plant tissues has already been well documented in the literature [25,26]. Limited information exists concerning the utilization of $\mathrm{CA}$ as a chelating agent for phytoextraction of $\mathrm{Pb}$ with L. minor-common duckweed [27] and some other plants. Further, the type of plant species also affects its applicability through root exudates and inherent metal (e.g., Cd) accumulation traits [28]. However, no such study has been conducted involving Alternanthera bettizikianna as a phytoextraction plant. Therefore, the objective of the present study was to evaluate if CA can enhance the phytoextraction potential of Alternanthera bettizikianna. The study examined the natural as well as CA-assisted phytoextraction potential of Alternanthera bettizikianna for remediation of $\mathrm{Pb}$ contaminated soils. The study results help in elucidating the phytoextraction potential of CA and onward application of this technology 
to remediate $\mathrm{Pb}$ polluted soils under field conditions. Due to its biodegradable nature, $\mathrm{CA}$ application would ultimately serve as an environmentally friendly and sustainable strategy to manage soils contaminated with $\mathrm{Pb}$.

\section{Materials and Methods}

\subsection{Experimental Site}

Soil samples were collected from the field of the University of Agriculture, Faisalabad, Pakistan. The random samples of soil were mixed, and a homogenous compost sample was prepared. The experiment was carried out in the Botanical Garden of GC University Faisalabad (GCUF). The soil was grounded with a wooden roller, sieved through $2 \mathrm{~mm}$, and systematically mixed. The physico-chemical characteristics of the soil used in this experiment are presented in Table 1 . The parameters employed here were measured using the methods described by [29].

Table 1. Soil physico-chemical properties.

\begin{tabular}{|c|c|}
\hline Texture & Clay Soil \\
\hline Sand (\%) & 21.0 \\
\hline Silt (\%) & 16.0 \\
\hline Clay $(\%)$ & 63.0 \\
\hline $\mathrm{EC}_{\mathrm{e}}\left(\mathrm{dS} \mathrm{m}^{-1}\right)$ & 2.79 \\
\hline pH (1: 2.5 soil to water ratio) & 7.86 \\
\hline Organic matter (\%) & 0.54 \\
\hline $\operatorname{SAR}\left(\mathrm{mmol}_{\mathrm{C}}{ }^{-1}\right) 1 / 2$ & 6.27 \\
\hline $\mathrm{HCO}_{3}\left(\mathrm{mmol} \mathrm{L}^{-1}\right)$ & 3.33 \\
\hline Available P (mg kg $\left.{ }^{-1}\right)$ & 2.21 \\
\hline $\mathrm{SO}_{4}^{2-}\left(\mathrm{mmol} \mathrm{L}^{-1}\right)$ & 6.38 \\
\hline $\mathrm{Cl}^{-}(\mathrm{mmol} \mathrm{L}-1)$ & 2.29 \\
\hline $\mathrm{K}^{+}\left(\mathrm{mmol} \mathrm{L}^{-1}\right)$ & 0.04 \\
\hline $\mathrm{Na}^{2+}(\mathrm{mmol} \mathrm{L}-1)$ & 3.52 \\
\hline $\mathrm{Ca}^{2+}+\mathrm{Mg}^{2+}\left(\mathrm{mmol} \mathrm{L}^{-1}\right)$ & 3.61 \\
\hline Available $\mathrm{Zn}^{2+}\left(\mathrm{mg} \mathrm{kg}^{-1}\right)$ & 0.76 \\
\hline Available $\mathrm{Cu}^{2+}\left(\mathrm{mg} \mathrm{kg}^{-1}\right)$ & 0.21 \\
\hline Available $\mathrm{Pb}^{2+}\left(\mathrm{mg} \mathrm{kg}^{-1}\right)$ & 0.43 \\
\hline
\end{tabular}

\subsection{Experimental Design and Treatments}

The experiment was arranged in a complete randomized design where three replicates of lead $(\mathrm{Pb})$ concentrations viz. $0,200,500$, and $1000 \mathrm{mg} \mathrm{kg}^{-1}$ of soil, the sieved soil were spiked. All plastic pots were filled with $3 \mathrm{~kg}$ of clay soil that was saturated from top to bottom with normal irrigation water. The preferred moisture level was maintained at $70 \%$. Citric acid levels $(0,250,500 \mu \mathrm{M})$ were applied four times with an interval of seven days. Four seedlings of Alternanthera bettzickiana (having a similar size) were grown in each pot. After 15 days of growth of these seedlings, fertilizers were applied in the form of urea, diammonium phosphate (DAP), and potassium bisulfate $\left(\mathrm{K}_{2} \mathrm{SO}_{4}\right)$ which was applied as $2.19,1.36$, and $2.40 \mathrm{~g}$ per pot, respectively. In the case of controlled plants, the plants were irrigated with tap water as and when required.

\subsection{Harvesting of the Plants}

After a growing period of 90 days, the plants were harvested. After harvesting, the roots, leaves, and stems were separated. The samples were then first rinsed with normal water, then with $2 \% \mathrm{HCl}$ solution, and finally with purified water to remove any aerial deposition. The roots and shoots were oven-dried at $70{ }^{\circ} \mathrm{C}$ for 48 hours to get constant roots and shoot dry weights and roots dry weight and shoot dry weight were recorded. 


\subsection{Determination of Pigment Contents}

The top-most fully expanded leaves were used to extract the pigments. After eight weeks of the application of $\mathrm{Pb}$ toxicity, the plants were harvested for the determination of enzymes such as chlorophyll and carotenoids and were determined by spectrophotometer [30]. The photosynthetic contents were extracted from a known fresh weight of leaves in $85 \%(v / v)$ aqueous acetone. The extract was centrifuged at $4000 \mathrm{rpm}$ for $10 \mathrm{~min}$; the supernatant was then taken and diluted with $85 \%$ aqueous acetone to get a suitable concentration for spectrophotometric measurements. The extinction was measured against a blank of pure $85 \%$ aqueous acetone at a wavelength of 452,644 , and $663 \mathrm{~nm}$.

\subsection{Determination of Electrolyte Leakage}

The electrical conductivity of leaf samples was determined while A. bettzickiana was growing and the electrical conductivity of the leave samples was measured using the electric conductivity meter. We measured the initial $\mathrm{EC}_{1}$ and final $\mathrm{EC}_{2}$. Finally, EL was calculated through the described method by [31]:

$$
\mathrm{EL}=\left(\mathrm{EC}_{1} / \mathrm{EC}_{2}\right) \times 100
$$

\subsection{Determination of Antioxidant Enzymes and ROS}

Antioxidant enzymes such as SOD, POD, APX, CAT, MDA, and $\mathrm{H}_{2} \mathrm{O}_{2}$ in roots and leaves of plants were determined using a spectrophotometer [4,31]. The leaves and roots of the plants were sampled for enzymatic analysis after 8 weeks of application of treatments. The samples were homogenized in $0.05 \mathrm{M}$ phosphate buffer $(\mathrm{pH} 7.8)$ by grinding with a mortar and pestle under a chilled condition with liquid nitrogen. The homogenate was filtered through four layers of muslin cloth and centrifuged at 12,000 rpm for $10 \mathrm{~min}$ at $4{ }^{\circ} \mathrm{C}$, and the supernatants were used for measurements of SOD and POD activities.

\subsection{Determination of Catalase}

CAT, EC activity was determined according to methods [32]. The assay mixture $(3.0 \mathrm{~mL})$ consisted of $100 \mu \mathrm{L}$ enzyme extract, $100 \mu \mathrm{L} \mathrm{H}_{2} \mathrm{O}_{2}(300 \mathrm{mM})$, and $2.8 \mathrm{~mL} 50 \mathrm{mM}$ phosphate buffer with $2 \mathrm{mM}$ EDTA (pH 7.0). The CAT activity was assayed by monitoring the decrease in the absorbance at $240 \mathrm{~nm}$ because of $\mathrm{H}_{2} \mathrm{O}_{2}$ disappearance $\left(\varepsilon=39.4 \mathrm{mM}^{-1} \mathrm{~cm}^{-1}\right)$.

\subsection{Determination of Ascorbate Peroxidase}

Ascorbate peroxidase (APX) activity was assayed according to the method described [33]. The reaction mixture consisted of $100 \mu \mathrm{L}$ enzyme extract, $100 \mu \mathrm{L}$ ascorbate $(7.5 \mathrm{mM}), 100 \mu \mathrm{L}$ $\mathrm{H}_{2} \mathrm{O}_{2}(300 \mathrm{mM})$, and $2.7 \mathrm{~mL} 25 \mathrm{mM}$ potassium phosphate buffer with $2 \mathrm{mM}$ EDTA (pH 7.0). The oxidation of ascorbate was determined by the change in the absorbance at $290 \mathrm{~nm}$ $\left(\varepsilon=2.8 \mathrm{mM}^{-1} \mathrm{~cm}^{-1}\right)$.

\subsection{Determination of Hydrogen Peroxide and Lead Contents}

$\mathrm{H}_{2} \mathrm{O}_{2}$ was extracted by homogenizing $50 \mathrm{mg}$ leaf or root tissues with $3 \mathrm{~mL}$ of phosphate buffer ( $50 \mathrm{mM}, \mathrm{pH}$ 6.5). Then, the homogenate was centrifuged at $6000 \mathrm{rpm}$ for $25 \mathrm{~min}$. To measure $\mathrm{H}_{2} \mathrm{O}_{2}$ content, $3 \mathrm{~mL}$ of extracted solution was mixed with $1 \mathrm{~mL}$ of $0.1 \%$ titanium sulfate in $20 \%(v / v) \mathrm{H}_{2} \mathrm{SO}_{4}$, and the mixture then centrifuged at $6000 \mathrm{rpm}$ for $15 \mathrm{~min}$. The intensity of the yellow color of the supernatant was measured at $410 \mathrm{~nm} . \mathrm{H}_{2} \mathrm{O}_{2}$ content was computed by using the extinction coefficient of $0.28 \mu \mathrm{mol}^{-1} \mathrm{~cm}^{-1}$. Pb contents in root, stem, and leaves were determined by flame atomic absorption spectrometry, and data were analyzed by using an appropriate statistical package [31]. The digestion of plant samples was done on a hot plate by adding $\mathrm{HCIO}_{4}$ and $\mathrm{HNO}_{3}$ in a given ratio (1:5) and final $\mathrm{Pb}$ contents were recorded by atomic absorption spectrophotometer. 


\subsection{Statistical Analysis}

The three replicate means were used of all values which were used in this study. By the use of (SPSS, IBM, 2009) with version 16.0, the ANOVA was applied. Tukey's post-hoc test was applied to different treatment means to check the standard deviation and significant difference.

\section{Results}

\subsection{Plant Growth and Biomass}

The difference in A. Bettzickiana growth and biomass parameters, including plants height, roots length, leave the area, the number of seedlings per plant, and dry weights of root and shoot, is given in Figure 1. A. Bettzickiana plant presented an important effect of $\mathrm{Pb}$ stress during the experiment period dry biomass and growth increased. A decreased plant height, dry biomass, and the leaf area of plants were allied with the maximum application of $\mathrm{Pb}$. At maximum level of CA $(500 \mu \mathrm{M})$, the plants height increased by $35,82,77,43 \%$ and leaf area increased by $32,97,71,64 \%$ at $\mathrm{Pb}$ levels $\left(0,200,500,1000 \mathrm{mg} \mathrm{kg}^{-1}\right)$, respectively. Furthermore, shoot dry weight increased by 33, 106, 92, 81\% and root dry weight increased by $63,247,190$, $132 \%$ at $\mathrm{Pb}$ levels $\left(0,200,500,1000 \mathrm{mg} \mathrm{kg}^{-1}\right)$, respectively at CA level $(500 \mu \mathrm{M})$.
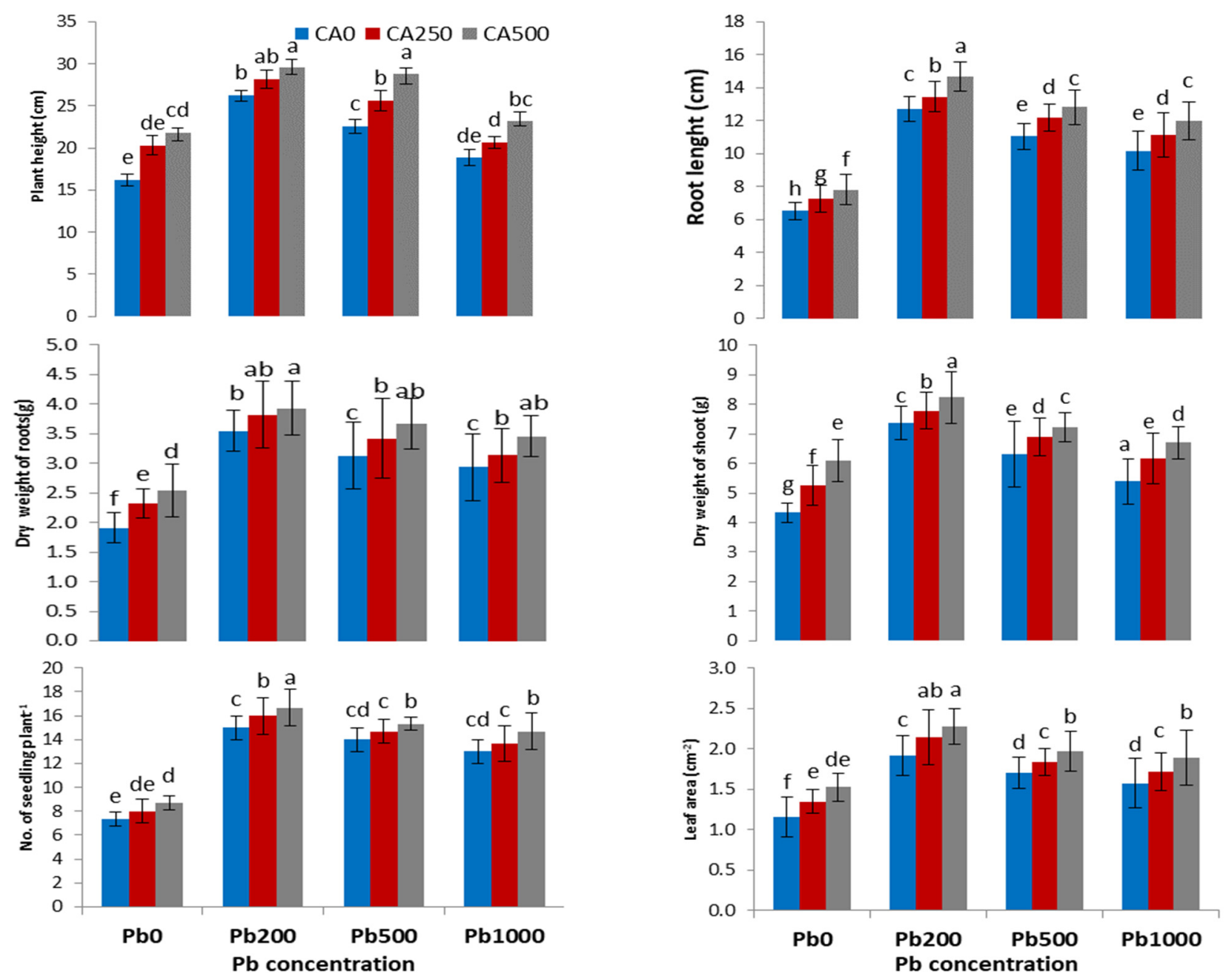

Figure 1. Effect of citric acid and $\mathrm{Pb}$ treatments on the plant-on-plant growth parameters of A. bettzickiana (Regel) G. Nicholson. Citric acid was applied at 0,250 , and $500(\mu \mathrm{M})$ and $\mathrm{Pb}$ application rates were $0,200,500,1000\left(\mathrm{mg} \mathrm{kg}^{-1}\right)$. Bars sharing the same letters do not differ significantly $p<0.05$. 


\subsection{Photosynthetic Pigment}

The effect of CA on A. bettzickiana under Pb stress, chlorophyll contents, and carotenoids was measured and presented in Figure 2. All the chlorophyll contents were significantly increased with increasing concentration of CA. At maximum level of CA $(500 \mu \mathrm{M})$, Chl a increased by $44,141,118,77 \%$ and $C h l b$ increased by $42,100,63,44 \%$ at Pb levels $(0,200$, $\left.500,1000 \mathrm{mg} \mathrm{kg}^{-1}\right)$, respectively. Furthermore, carotenoids increased by $32,117,62,50 \%$ at $\mathrm{Pb}$ levels $\left(0,200,500,1000 \mathrm{mg} \mathrm{kg}^{-1}\right)$, respectively at CA level $(500 \mu \mathrm{M})$.
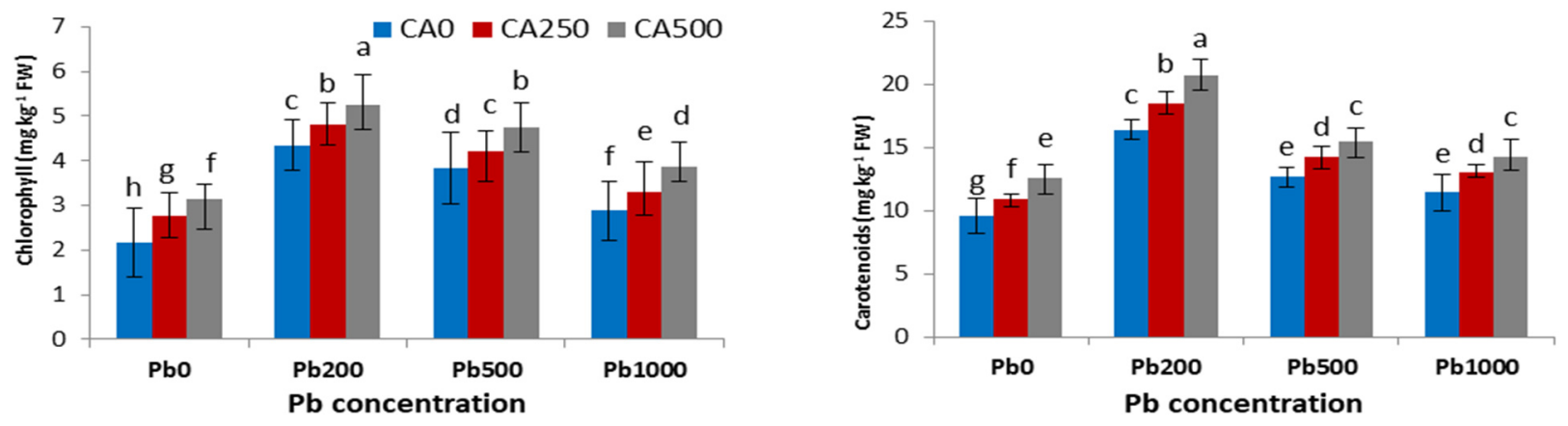

Figure 2. Effect of citric acid and $\mathrm{Pb}$ treatments on the plant on chlorophyll and carotenoids of A. bettzickiana (Regel) G. Nicholson. Citric acid was applied at 0,250 , and $500(\mu \mathrm{M})$ and Pb application rates were $0,200,500,1000\left(\mathrm{mg} \mathrm{kg}^{-1}\right)$. Bars sharing the same letters do not differ significantly $p<0.05$.

\subsection{Plant Physiological Parameters (Concentration of $\mathrm{H}_{2} \mathrm{O}_{2}$ and $M D A$ ) and Electrolyte Leakage}

The data regarding $\mathrm{H}_{2} \mathrm{O}_{2}$ in the leaves, roots presented in Figure 3, depict that a significant reduction in root and leaf $\mathrm{H}_{2} \mathrm{O}_{2}$ was recorded with an increase in CA at all $\mathrm{Pb}$ levels. The electrolyte leakage was also controlled with the presence of $\mathrm{CA}$ in the rooting media. EL decreased with the addition of CA at all $\mathrm{Pb}$ levels (Figure 3). The same is true with MDA in leaves and roots of $A$. bettzickiana. The physiological responses of $A$. bettzickiana under HMs stress have not been evaluated extensively in the literature. However, phytoextraction potential, physiological, and biochemical response of various plant species against HMs stress is not fully understood. Among other $\mathrm{HMs}$, lead $(\mathrm{Pb})$ is an inorganic pollutant with deleterious biotic effects.

\subsection{Activities of Antioxidant Enzymes and ROS}

Enzymatic activities such as POD and SOD of A. Bettzickiana in leaves and roots were without $\mathrm{Pb}$ and with $\mathrm{CA}$ in the soil. Antioxidant enzyme activities in roots and leaves considerably improved at $\mathrm{Pb}\left(500 \mathrm{mg} \mathrm{kg}^{-1}\right)$ and then reduced at $\mathrm{Pb}$ concentration $\left(1000 \mathrm{mg} \mathrm{kg}^{-1}\right)$ in Figure 4. At maximum level of CA $(500 \mathrm{~mL})$, SOD in root increased by $51,90,133,77 \%$ at Pb levels $\left(0,200,500,1000 \mathrm{mg} \mathrm{kg}^{-1}\right)$. Furthermore, POD in root increased by $38,67,79,60 \%$ at Pb levels $0,200,500,1000\left(\mathrm{mg} \mathrm{kg}^{-1}\right)$, respectively at CA level $500 \mu \mathrm{M}$. The electrolyte leakage (EL) was significantly decreased with increasing concentration of CA. At maximum level of CA $(500 \mu \mathrm{M})$, EL in root decreased by 16, 39, 36, $20 \%$ at $\mathrm{Pb}$ levels $\left(0,200,500,1000 \mathrm{mg} \mathrm{kg}^{-1}\right)$. 

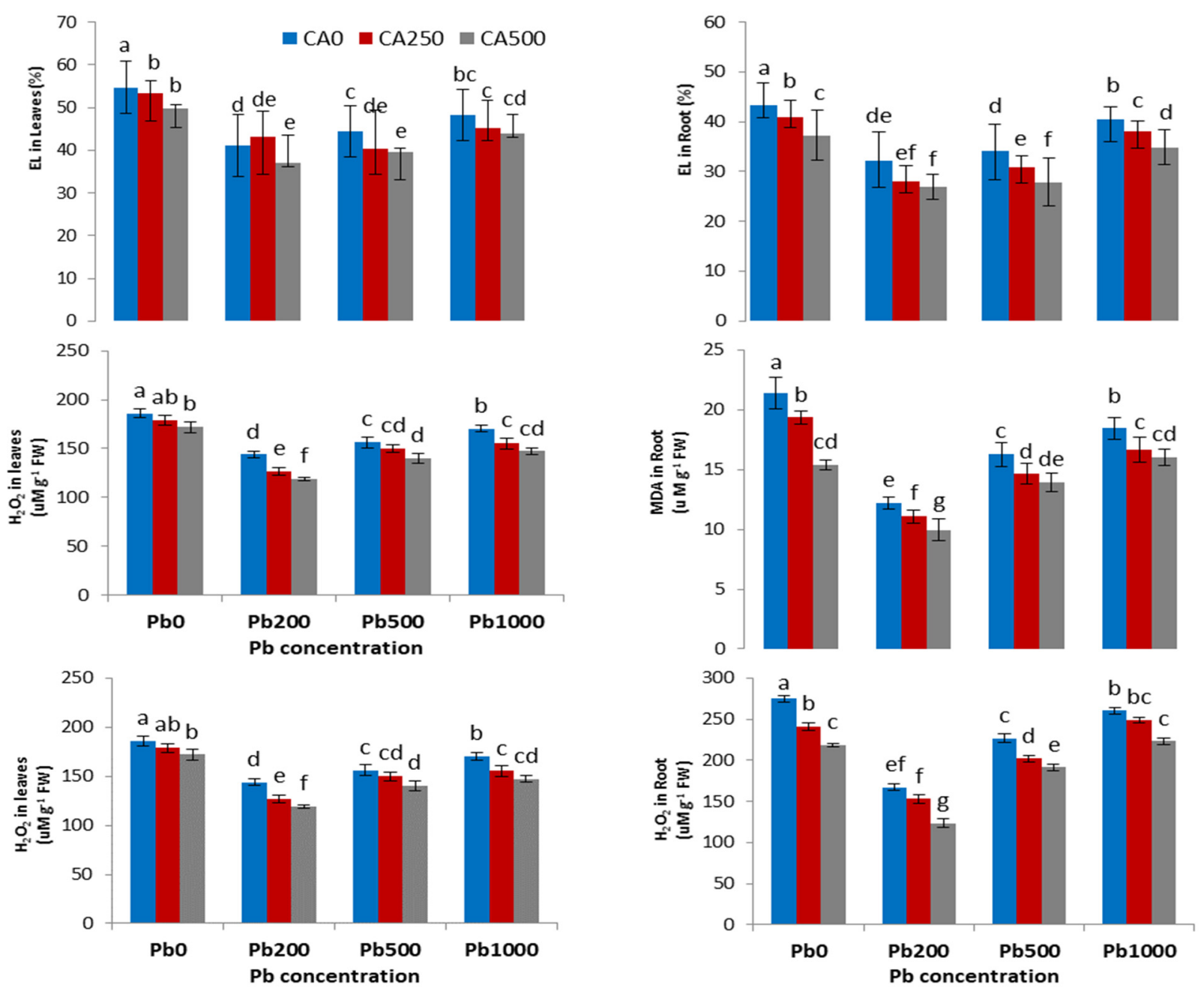

Figure 3. Effect of citric acid and $\mathrm{Pb}$ treatments on the plant on physiological parameters of A. bettzickiana (Regel) G. Nicholson. Citric acid was applied at 0,250 , and $500(\mu \mathrm{M})$ and $\mathrm{Pb}$ application rates were $0,200,500,1000\left(\mathrm{mg} \mathrm{kg}^{-1}\right)$. Bars sharing the same letters do not differ significantly $p<0.05$.

\subsection{Metal Uptake}

Enhancing the concentration of $\mathrm{Pb}$ in soil considerably improved the uptake of $\mathrm{Pb}$ in shoots and roots. The effects of $\mathrm{CA}$ on $\mathrm{A}$. bettzickiana under Pb stress, Pb concentration in the root, and shoot were measured as given in Figure 5. The Pb concentrations were significantly decreased with the maximum application of CA. At the extreme level of CA $(500 \mathrm{~mL}), \mathrm{Pb}$ concentration in root and shoot decreased. 

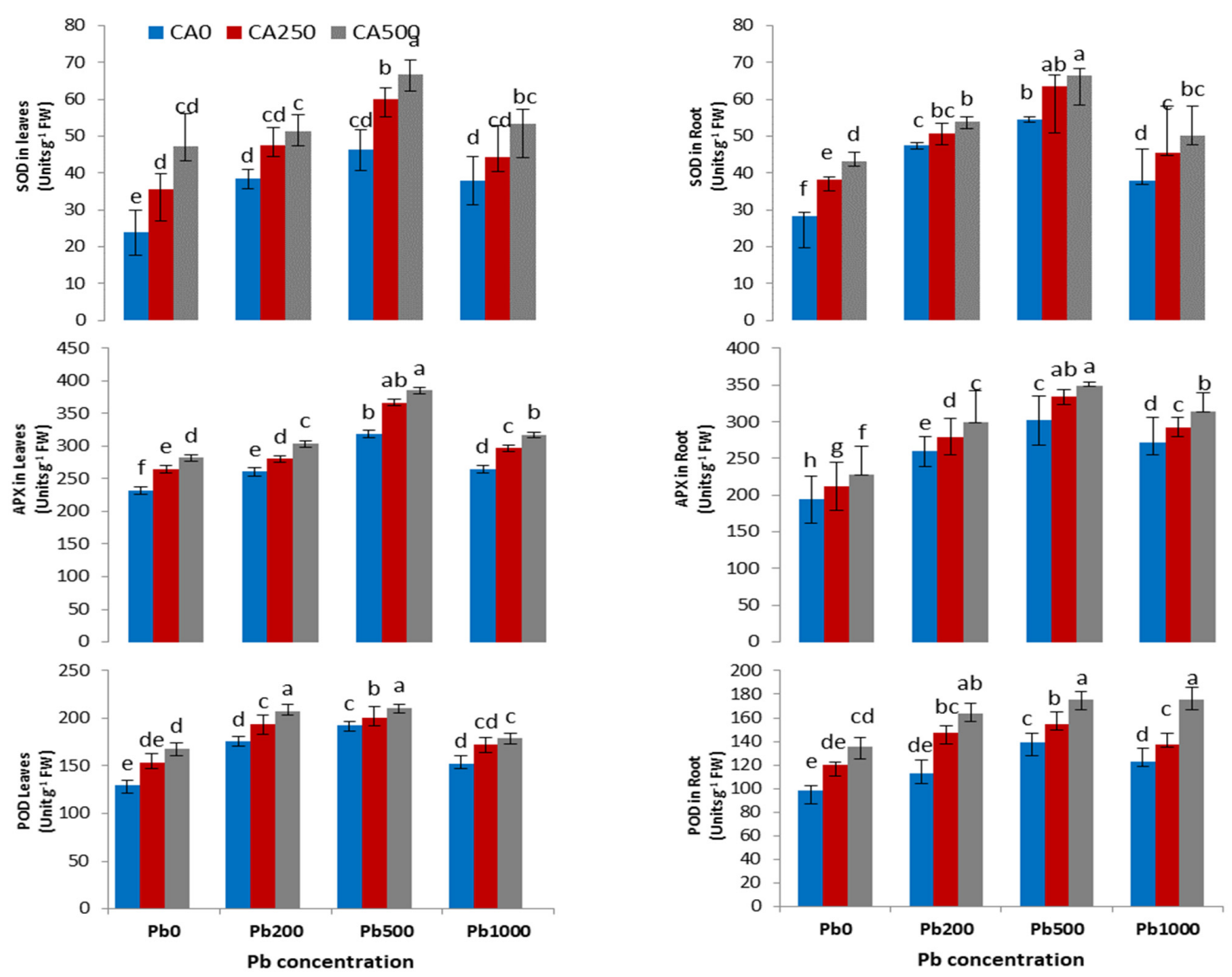

Figure 4. Effect of citric acid and $\mathrm{Pb}$ treatments on the plant on enzymatic parameters in leaves and roots of $A$. bettzickiana (Regel) G. Nicholson. Citric acid was applied at 0, 250, and $500(\mu \mathrm{M})$ and Pb application rates were 0, 200, 500, $1000\left(\mathrm{mg} \mathrm{kg}^{-1}\right)$. Bars sharing the same letters do not differ significantly $p<0.05$.
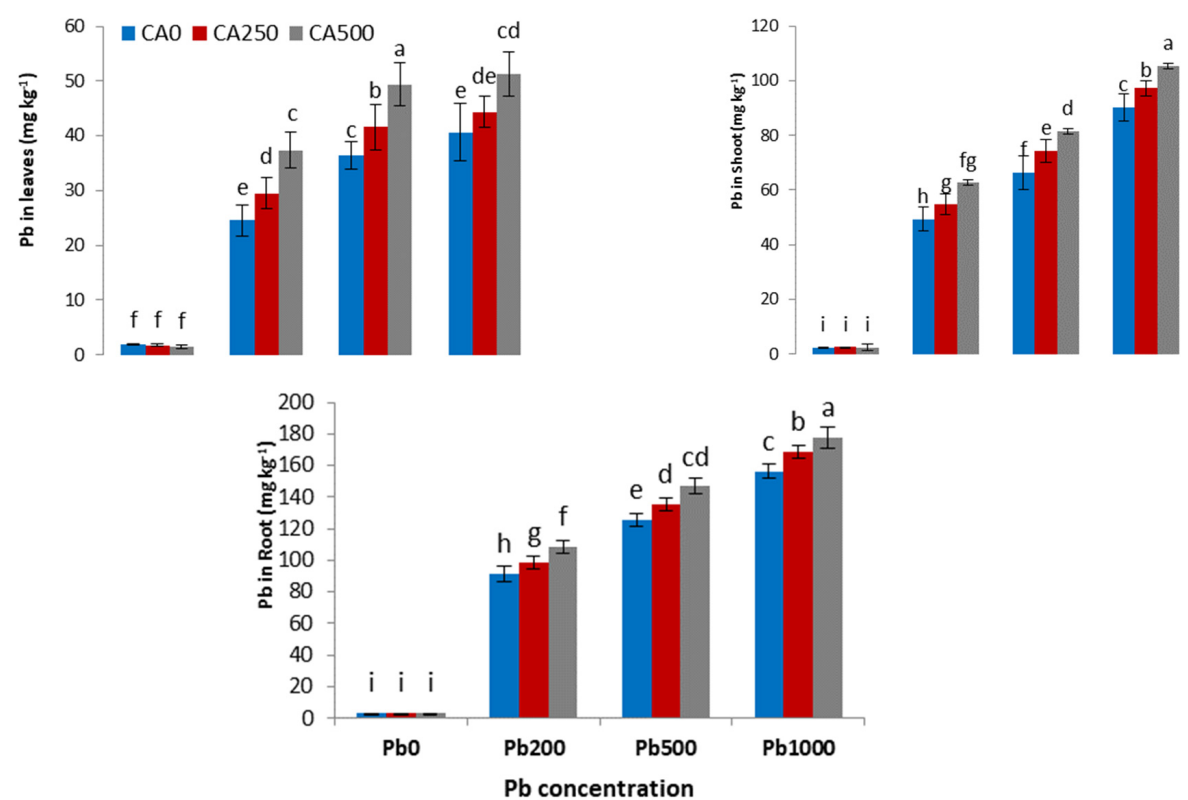

Figure 5. Effect of citric acid and $\mathrm{Pb}$ treatments on $\mathrm{Pb}$ concentrations in the root, shoot, and leaves of A. bettzickiana (Regel) G. Nicholson. Citric acid was applied at 0,250 , and $500(\mu \mathrm{M})$ and $\mathrm{Pb}$ application rates were $0,200,500,1000\left(\mathrm{mg} \mathrm{kg}^{-1}\right)$. Bars sharing the same letters do not differ significantly $p<0.05$. 


\section{Discussion}

\subsection{Growth Parameters}

In plants, ecotoxicity induced by heavy metals depends upon numerous factors like plant genotype, plant species, the concentration of heavy metals, and exposure duration [34]. Metabolic processes of plants were interfered by $\mathrm{Pb}$, which ultimately leads to the deterioration of plant's growth and development [2], and mostly to a reduction in protein synthesis and photosynthesis and devastation at the cellular as well as subcellular levels [35]. Similar toxic effects of Pb were reported in Brassica napus [10] and A. bettzickiana $[8,36]$. Alike to other organic acids, the AA growth-promoting effect is established in the literature where organic acids like citric acid $(2.5,5$, and $10 \mathrm{mM})$, ascorbic acid $(5 \mathrm{mM})$, and glutamic acid ( 2.5 and $5 \mathrm{mM}$ ) were used for Brassica napus, sunflower, Solanum nigrum L., and Lemna minor L. [37,38], respectively in the existence of heavy metals stress. Lead is the most toxic HMs which stimulated various ultra-structural and physiological damages in plants [2]. The reduction in the plant biomass is exposed in Figure 1. HMS toxicity appeared because of the intrusion of $\mathrm{Pb}$ with the metabolism of the plant and also physiology $[39,40]$. The citric acid accumulation of $\mathrm{Pb}$ stressed plants considerably improved the plant biomass and development described in Figure 1. This might have occurred because of the significant role of citric acid in assisting many metabolic processes of the plant. Plant biomasses were enhanced in the Solanum nigrum L. plant by using CA concentration [37]. This study was furthermore verified by [41] and [42] who described the same promotion role of CA for the development of plants with Cd and Mn stress in Brassica napus L and J. effusus, respectively.

\subsection{Chlorophyll Contents}

Reduced chlorophyll contents were reported due to $\mathrm{Pb}$ stress by imposing negative effects on the photosynthetic efficiency and transpiration rate of plants. Disturbance in protein complexes, photosynthetic pigments, and chloroplast was reported by various researchers because of the increase in chlorophyllase activity under stress imposed by heavy metals [6,43]. Moreover, lead toxicity stimulated the negative effects on photosynthetic pigments. This could be the result of damage to the photosynthetic chloroplast, apparatus, and protein complex whenever plants indicated metal toxicity [17]. Therefore, chlorophyll breakdown occurs because of an increase in the activity of chlorophyllase due to metal toxicity [44] (Figure 2). However, application of CA reverses this effect and significantly enhances the chlorophyll contents of A. Bettzickiana.

\subsection{Antioxidant Enzyme Parameters and Reactive Oxygen Species}

In plants, $\mathrm{Pb}$ toxicity was previously observed in terms of higher MDA production and higher activities of antioxidant enzymes in A. bettzickiana [8], in Brassica napus [10], and in S. nigrum by [45]. Similar results were reported by [46] for A. bettzickiana when exposed to $\mathrm{Cd}$ stress. The addition of $\mathrm{AA}$ along with $\mathrm{Pb}$ enhanced the defensive mechanisms of a plant which assisted in overcoming the lipid peroxidation produced by $\mathrm{Pb}$ stress. An alike mechanism was documented by [46] in A. bettzickiana under citric acid and Cd. Some antioxidant enzymes (APX, SOD, and CAT), along with other metabolites, achieve a precise role in the adaptation and tolerance of plants to $\mathrm{Pb}$ ecotoxicity [47]. At $10 \mathrm{mM} \mathrm{Pb}$, the activities of antioxidant enzymatic tended to decline while MDA production continued to rise, which resulted in reduced nutrient uptake and disruption of plant metabolic pathways [22,46]. Enhanced MDA production is generally observed as a sign of severe oxidative stress beneath metal stress which ultimately destroys the plant cells [48,49]. Some important metabolites and also antioxidant enzymes take part in an essential role in the development of plants and adaptation due to mental stress. Oxidative stress changes enzymatic activities, which are important to alleviate metal toxicity [50].

Reduction in the antioxidant enzyme activities and oxidative parameters are shown in Figure 3. Reduction in the antioxidant enzymatic activity and also oxidative parameters due to lead stressed plants were observed in the recent research and this reduction was 
measured due to the $\mathrm{Pb}$ uptake in the plant cells. The enhancement of the antioxidant enzyme activities with citric acid and $\mathrm{Pb}$ described that $\mathrm{CA}$ could enhance the enzyme activities in A. Bettizikianna. Ref. [42] described the remarkable role of citric acid by increasing the antioxidant enzyme activities, hence, intervening metal-induced oxidative toxicity in J. effusus plant. The improvement in $\mathrm{H}_{2} \mathrm{O}_{2}, \mathrm{MDA}$, and electrolyte leakage due to toxicity of metal for the damage of liquid peroxidation and plasma membrane, can inhibit plant development [46]. In the recent study, the decrease in hydrogen peroxide, EL, and MDA by using citric acid documented the positive role of $\mathrm{CA}$ besides the $\mathrm{Pb}$ stress and it shows that CA plays an important role alleviating oxidative stress caused under $\mathrm{Pb}$ contamination. Some related results of the positive role of CA were reported in J. effusus [42].

\subsection{Antioxidant Enzyme Parameters and Reactive Oxygen Species}

In plants, $\mathrm{Pb}$ toxicity was previously observed in terms of higher MDA production and higher activities of antioxidant enzymes in A. bettzickiana by [8], in Brassica napus by [10], and in S. nigrum by [45]. Similar results were reported by [46] for A. bettzickiana when exposed to $\mathrm{Cd}$ stress. The addition of AA along with $\mathrm{Pb}$ enhanced the defensive mechanisms of a plant which assisted to overcome the lipid peroxidation produced by $\mathrm{Pb}$ stress. An alike mechanism was documented by [46] in A. bettzickiana under citric acid and Cd. Some antioxidant enzymes (APX, SOD, and CAT), along with other metabolites, achieve a precise role in the adaptation and tolerance of plants to Pb ecotoxicity [47]. At $10 \mathrm{mM} \mathrm{Pb}$, the activities of antioxidant enzymatic tended to decline while MDA production continued to rise, which resulted in reduced nutrient uptake and disruption of plant metabolic pathways [22,46]. Enhanced MDA production is generally observed as a sign of severe oxidative stress beneath metal stress which ultimately destroys the plant cells $[48,49]$. Some important metabolites and also antioxidant enzymes take part in an essential role in the development of plants and adaptation due to metal stress. Oxidative stress changes enzymatic activities, which are important to alleviate metal toxicity [50]. Reduction in the antioxidant enzyme activities and oxidative parameters is shown in Figure 3. Reduction in the antioxidant enzymatic activity, also oxidative parameters due to lead stressed plants, were observed in the recent research and this reduction was measured due to the Pb uptake in the plant cells. The enhancement of the antioxidant enzyme activities with citric acid and $\mathrm{Pb}$ described that $\mathrm{CA}$ could enhance the enzyme activities in A. Bettizikianna. Ref. [42] described the remarkable role of citric acid by increasing the antioxidant enzyme activities, hence, intervening metal-induced oxidative toxicity in J. effusus plant. The improvement in $\mathrm{H}_{2} \mathrm{O}_{2}, \mathrm{MDA}$, and electrolyte leakage due to toxicity of metal for the damage of liquid peroxidation and plasma membrane can inhibit plant development [46]. In the recent study, the decrease in hydrogen peroxide, EL, and MDA by using the citric acid documented the positive role of $\mathrm{CA}$ besides the $\mathrm{Pb}$ stress and it shows that $\mathrm{CA}$ plays an important role alleviating oxidative stress caused under $\mathrm{Pb}$ contamination. Some related results of the positive role of CA were reported in J. effusus [42].

\subsection{Lead Uptake}

In-plant tissues, heavy metals accumulation is associated with their concentration level in the environment. In the current study, the concentration level of $\mathrm{Pb}$ in all parts of $A$. bettzickiana increased with the cumulative concentration of applied $\mathrm{Pb}$ in soil. The greater uptake of lead in roots compared to stems and leaves was because of the direct contact of roots to $\mathrm{Pb}$ in soil [16]. Our findings agreed with those of [8,46], who established the phytoextraction potential of $A$. bettzickiana for $\mathrm{Pb}$ and $\mathrm{Cd}$, correspondingly (Figure 5). Though some studies recommended that $\mathrm{Pb}$ generally accumulated in the roots, and only a slight fraction can be translocated to the aerial parts of plants [19,51]. A. bettzickiana plant accumulated Pb from media [8] like other plants such as B. napus, L. minor, and Typha latifolia $[10,38]$. On the other hand, some plant species like T. oriental constrained the $\mathrm{Pb}$ accumulation in roots [16]. AA addition under $\mathrm{Pb}$ stress meaningly increased the $\mathrm{Pb}$ uptake and its accumulation in roots, leaves, and stems, comparable to the findings stated by [45]. Organic acids and AA offer 
the protons and electrons and built complexions to be readily uptaken by the roots of the plant $[45,52]$. Ref. [45] established that indole-3-acetic acid suggestively improved the uptake of $\mathrm{Pb}, \mathrm{Zn}$, and $\mathrm{Cd}$ in Solanum nigrum.

Metal uptake in the plant is directly correlated to the $\mathrm{Pb}$ levels in plant development. In a recent study, $\mathrm{Pb}$ concentration in a part of the plants, such as the root and shoot of A. Bettzickiana, was improved and shown in Figure 5 [53]. As we enhanced the $\mathrm{Pb}$ contents in the soil, our finding of more metal accumulation of the Pb level in roots rather than the shoots and leaves showed the potential that can help the metal-induced damages [42]. In A. Bettzickiana, CA application considerably improved the metal uptake and its concentration in stem, root, and leaves in comparison with the lead alone treated plant. The results related to $\mathrm{P}$ dynamics in different parts of the A. Bettzickiana show that $\mathrm{CA}$ application enhanced the phytoextraction potential of $\mathrm{Pb}$ from the $\mathrm{Pb}$ spiked soil. Despite the fact that application of CA significantly enhanced the phytoextraction potential of $A$. Bettzickiana, this study was conducted under controlled conditions. Its onward confirmation under natural field conditions involving $\mathrm{Pb}$ contaminated soil would be helpful in authentication of these results and its further recommendation at a large scale. Moreover, rigorous studies involving different climatic and soil conditions would also be helpful in its confirmation and authentication under natural field conditions.

\section{Conclusions}

Citric acid played an important part in enhancing the development of A. bettizikianna in tolerating $\mathrm{Pb}$ toxicity. The $\mathrm{Pb}$ stress decreased the plant biomass, plant development, chlorophyll content, antioxidant enzymes, and increased the oxidative stress parameters of plants. While the application of citric acid considerably enhanced the photosynthetic contents and morphological parameters by inhibiting the oxidative damage of cells caused under $\mathrm{Pb}$ stress. Our results also showed that $A$. Bettzickiana plant can discharge a significant quantity of pollutants such as $\mathrm{Pb}$ and is rigorous in working like hyper-accumulator plants confirming the study hypothesis. The application of CA remarkably improved the amount of $\mathrm{Pb}$ uptake by this hedge plant via enhancing plant growth and antioxidant defense system of plants. However, we suggest further field investigations to explore the detailed mechanism regarding the phytoremediation of $\mathrm{Pb}$ through A. bettizikianna assisted by $\mathrm{CA}$ under natural field conditions.

Author Contributions: Conceptualization, U.K. and M.I. (Muhammad Ibrahim); methodology, U.K.; software, M.I. (Muhammad Imtiaz) and A.D.; formal analysis, U.K., A.A.F., M.I. (Muhammad Ibrahim) and A.D.; investigation, M.Y., F.J. and M.I. (Muhammad Imtiaz); resources, M.I. (Muhammad Ibrahim); writing — original draft preparation, U.K. and A.S.; writing-review and editing, F.A., S.A.; supervision, M.I. (Muhammad Ibrahim), F.A., S.A.; project administration, M.Y.; funding acquisition, M.I. (Muhammad Ibrahim), A.A.F., F.A. All authors have read and agreed to the published version of the manuscript.

Funding: The authors want to acknowledge Government College University Faisalabad and Higher Education Commission (HEC), Pakistan for their financial assistance under HEC-NRPU-5635 for financial support.

Institutional Review Board Statement: Not applicable.

Informed Consent Statement: Not applicable.

Data Availability Statement: Not applicable.

Acknowledgments: The authors acknowledge the financial support by the Natural Sciences and Engineering Research Council of Canada (NSERC), the partial research funding and editorial supports is appreciated.

Conflicts of Interest: The authors declare no conflict of interest. The funders had no role in the design of the study; in the collection, analyses, or interpretation of data; in the writing of the manuscript, or in the decision to publish the results. 


\section{References}

1. Mühlbachová, G. Soil microbial activities and heavy metal mobility in long-term contaminated soils after addition of EDTA and EDDS. Ecol. Eng. 2011, 37, 1064-1071. [CrossRef]

2. Sharma, P.; Dubey, R.S. Lead toxicity in plants. Braz. J. Plant Physiol. 2005, 17, 35-52. [CrossRef]

3. Khopkar, S. Environmental Pollution Monitoring and Control; New Age International: New Delhi, India, 2007.

4. Zhang, R.; Zhou, Y.; Yue, Z.; Chen, X.; Cao, X.; Xu, X.; Xing, Y.; Jiang, B.; Ai, X.; Huang, R. Changes in photosynthesis, chloroplast ultrastructure, and antioxidant metabolism in leaves of sorghum under waterlogging stress. Photosynth. 2019, 57, 1076-1083. [CrossRef]

5. Tabelin, C.B.; Corpuz, R.D.; Igarashi, T.; Villacorte-Tabelin, M.; Alorro, R.D.; Yoo, K.; Raval, S.; Ito, M.; Hiroyoshi, N. Acid mine drainage formation and arsenic mobility under strongly acidic conditions: Importance of soluble phases, iron oxyhydroxides/oxides and nature of oxidation layer on pyrite. J. Hazard. Mater. 2020, 399, 122844. [CrossRef] [PubMed]

6. Afshan, S.; Ali, S.; Bharwana, S.A.; Rizwan, M.; Farid, M.; Abbas, F.; Ibrahim, M.; Mehmood, M.A.; Abbasi, G.H. Citric acid enhances the phytoextraction of chromium, plant growth, and photosynthesis by alleviating the oxidative damages in Brassica napus L. Environ. Sci. Pollut. Res. 2015, 22, 11679-11689. [CrossRef] [PubMed]

7. Pourrut, B.; Jean, S.; Silvestre, J.; Pinelli, E. Lead-induced DNA damage in Vicia faba root cells: Potential involvement of oxidative stress. Mutat. Res. Toxicol. Environ. Mutagen. 2011, 726, 123-128. [CrossRef]

8. Tauqeer, H.M.; Ali, S.; Rizwan, M.; Ali, Q.; Saeed, R.; Iftikhar, U.; Ahmad, R.; Farid, M.; Abbasi, G.H. Phytoremediation of heavy metals by Alternanthera bettzickiana: Growth and physiological response. Ecotoxicol. Environ. Saf. 2016, 126, 138-146. [CrossRef]

9. Shahid, M.; Ferrand, E.; Schreck, E.; Dumat, C. Behavior and impact of zirconium in the soil-plant system: Plant uptake and phytotoxicity. Rev. Environ. Contam. Toxicol. 2013, 221, 107-127.

10. Shakoor, M.B.; Ali, S.; Hameed, A.; Farid, M.; Hussain, S.; Yasmeen, T.; Najeeb, U.; Bharwana, S.A.; Abbasi, G.H. Citric acid improves lead $(\mathrm{pb})$ phytoextraction in brassica napus L. by mitigating pb-induced morphological and biochemical damages. Ecotoxicol. Environ. Saf. 2014, 109, 38-47. [CrossRef]

11. Jing, Y.-D.; He, Z.-L.; Yang, X.-E. Role of soil rhizobacteria in phytoremediation of heavy metal contaminated soils. J. Zhejiang Univ. Sci. B 2007, 8, 192-207. [CrossRef]

12. Kambhampati, M.S.; Vu, V.T. EDTA Enhanced Phytoremediation of Copper Contaminated Soils Using Chickpea (Cicer aeritinum L.). Bull. Environ. Contam. Toxicol. 2013, 91,310-313. [CrossRef]

13. Pilon-Smits, E. Phytoremediation. Annu. Rev. Plant Biol. 2005, 56, 15-39. [CrossRef]

14. Ahmad, K.; Khan, Z.I.; Ibrahim, M.; Ashraf, M.; Hussain, M. Evaluation of Nutritional Composition of Plant Species of Soone Valley in Punjab, Pakistan. J. Plant Nutr. 2010, 33, 496-517. [CrossRef]

15. Wang, D.; Guo, W.; Zhang, G.; Zhou, L.; Wang, M.; Lu, Y.; Cai, D.; Wu, Z. Remediation of Cr(VI)-Contaminated Acid Soil Using a Nanocomposite. ACS Sustain. Chem. Eng. 2017, 5, 2246-2254. [CrossRef]

16. Xu, X.; Chen, Q.; Mo, S.; Qian, Y.; Wu, X.; Jin, Y.; Ding, H. Transcriptome -wide modulation combined with morpho-physiological analyses of Typha orientalis roots in response to lead challenge. J. Hazard. Mater. 2020, 384, 121405. [CrossRef]

17. Mehmood, S.; Saeed, D.A.; Rizwan, M.; Khan, M.N.; Aziz, O.; Bashir, S.; Ibrahim, M.; Ditta, A.; Akmal, M.; Mumtaz, M.A.; et al. Impact of different amendments on biochemical responses of sesame (Sesamum indicum L.) plants grown in lead-cadmium contaminated soil. Plant Physiol. Biochem. 2018, 132, 345-355. [CrossRef]

18. Maroušek, J.; Kolář, L.; Strunecký, O.; Kopecký, M.; Bartoš, P.; Maroušková, A.; Cudlínová, E.; Konvalina, P.; Šoch, M.; Moudrý Jr, J.; et al. Modified biochars present an economic challenge to phosphate management in wastewater treatment plants. J. Clean. Prod. 2020, 272, 123015. [CrossRef]

19. Kumar, A.; Prasad, M.N.V. Plant-lead interactions: Transport, toxicity, tolerance, and detoxification mechanisms. Ecotoxicol. Environ. Saf. 2018, 166, 401-418. [CrossRef] [PubMed]

20. Anwer, S.; Ashraf, M.Y.; Hussain, M.; Ashraf, M.; Jamil, A. Citric acid mediated phytoextraction of cadmium by maize (Zea mays L.). Pak. J. Bot. 2012, 44, 1831-1836.

21. Freitas, E.V.; Nascimento, C.W.; Silva, W.M. Citric Acid-Assisted Phytoextraction of Lead in the Field: The Use of Soil Amendments. Water Air Soil Pollut. 2013, 225, 1-9. [CrossRef]

22. Farid, M.; Ali, S.; Saeed, R.; Rizwan, M.; Bukhari, S.A.H.; Abbasi, G.H.; Hussain, A.; Ali, B.; Zamir, M.S.I.; Ahmad, I. Combined application of citric acid and 5-aminolevulinic acid improved biomass, photosynthesis and gas exchange attributes of sunflower (Helianthus annuus L.) grown on chromium contaminated soil. Int. J. Phytoremediation 2019, 21, 760-767. [CrossRef]

23. Ding, Y.Z.; Li, Z.A.; Zou, B. Low-molecular weight organic acids and their ecological roles in soil. Soils 2005, 37, $243-250$.

24. Stávková, J.; Maroušek, J. Novel sorbent shows promising financial results on P recovery from sludge water. Chemosphere 2021, 276, 130097. [CrossRef]

25. Luo, C.; Shen, Z.; Li, X. Enhanced phytoextraction of $\mathrm{Cu}, \mathrm{Pb}, \mathrm{Zn}$ and $\mathrm{Cd}$ with EDTA and EDDS. Chemosphere 2005, 59, 1-11. [CrossRef] [PubMed]

26. Sinhal, V.K.; Srivastava, A.; Singh, V.P. EDTA and citric acid mediated phytoextraction of $\mathrm{Zn}, \mathrm{Cu}, \mathrm{Pb}$ and $\mathrm{Cd}$ through marigold (Tagetes erecta). J. Environ. Biol. 2010, 31, 255. [PubMed]

27. Haider, M.Z.; Hussain, S.; Ramzani, P.M.A.; Iqbal, M.; Iqbal, M.; Shahzad, T.; Fatima, M.; Khan, S.A.; Khan, I.; Shahid, M.; et al. Bentonite and Biochar Mitigate Pb Toxicity in Pisum sativum by Reducing Plant Oxidative Stress and Pb Translocation. Plants 2019, 8, 571. [CrossRef] [PubMed] 
28. Irshad, M.K.; Chen, C.; Noman, A.; Ibrahim, M.; Adeel, M.; Shang, J. Goethite-modified biochar restricts the mobility and transfer of cadmium in soil-rice system. Chemosphere 2020, 242, 125152. [CrossRef]

29. Sparks, D.L.; Page, A.L.; Helmke, P.A.; Loeppert, R.H. Methods of Soil Analysis: Part 2 Chemical and Microbiological Properties; John Wiley \& Sons: Hoboken, NJ, USA, 1965.

30. Lichtenthaler, H.K. Chlorophylls and Carotenoids: Pigments of Photosynthetic Biomembranes. In Methods in Enzymology; Academic Press: Orlando, FL, USA, 1987; Volume 148, pp. 350-382.

31. Dionisio-Sese, M.L.; Tobita, S. Antioxidant responses of rice seedlings to salinity stress. Plant Sci. 1998, 135, 1-9. [CrossRef]

32. Aebi, H. Catalase in vitro. Methods Enzymol. 1984, 105, 121-126.

33. Nakano, Y.; Asada, K. Hydrogen Peroxide is Scavenged by Ascorbate-specific Peroxidase in Spinach Chloroplasts. Plant Cell Physiol. 1981, 22, 867-880. [CrossRef]

34. Marrugo-Negrete, J.; Durango-Hernández, J.; Pinedo-Hernández, J.; Olivero-Verbel, J.; Díez, S. Phytoremediation of mercurycontaminated soils by Jatropha curcas. Chemosphere 2015, 127, 58-63. [CrossRef] [PubMed]

35. Vymazal, J. Removal of nutrients in various types of constructed wetlands. Sci. Total. Environ. 2007, 380, 48-65. [CrossRef] [PubMed]

36. Maroušek, J.; Bartoš, P.; Filip, M.; Kolář, L.; Konvalina, P.; Maroušková, A.; Moudrý, J.; Peterka, J.; Šál, J.; Šoch, M.; et al. Advances in the agrochemical utilization of fermentation residues reduce the cost of purpose-grown phytomass for biogas production. Energy Sources, Part A: Recover. Util. Environ. Eff. 2020, 1-11. [CrossRef]

37. Gao, Y.; Miao, C.; Mao, L.; Zhou, P.; Jin, Z.; Shi, W. Improvement of phytoextraction and antioxidative defense in Solanum nigrum L. under cadmium stress by application of cadmium-resistant strain and citric acid. J. Hazard. Mater. 2010, 181, 771-777. [CrossRef] [PubMed]

38. Sallah-Ud-Din, R.; Farid, M.; Saeed, R.; Ali, S.; Rizwan, M.; Tauqeer, H.M.; Bukhari, S.A.H. Citric acid enhanced the antioxidant defense system and chromium uptake by Lemna minor L. grown in hydroponics under Cr stress. Environ. Sci. Pollut. Res. 2017, 24, 17669-17678. [CrossRef]

39. Baker, A.J.; Walker, P.L. Ecophysiology of metal uptake by tolerant plants. Heavy Met. Toler. Plants Evol. Asp. 1990, 2, $155-165$.

40. Saradhi, P.P. Proline Accumulation Under Heavy Metal Stress. J. Plant Physiol. 1991, 138, 554-558. [CrossRef]

41. Maroušek, J.; Rowland, Z.; Valášková, K.; Král, P. Techno-economic assessment of potato waste management in developing economies. Clean Technol. Environ. Policy 2020, 22, 937-944. [CrossRef]

42. Najeeb, U.; Jilani, G.; Ali, S.; Sarwar, M.; Xu, L.; Zhou, W. Insights into cadmium induced physiological and ultra-structural disorders in Juncus effusus L. and its remediation through exogenous citric acid. J. Hazard. Mater. 2011, 186, 565-574. [CrossRef] [PubMed]

43. Habiba, U.; Ali, S.; Farid, M.; Shakoor, M.B.; Rizwan, M.; Ibrahim, M.; Abbasi, G.H.; Hayat, T.; Ali, B. EDTA enhanced plant growth, antioxidant defense system, and phytoextraction of copper by Brassica napus L. Environ. Sci. Pollut. Res. 2015, 22, 1534-1544. [CrossRef] [PubMed]

44. Hegedüs, A.; Erdei, S.; Horváth, G. Comparative studies of $\mathrm{H} 2 \mathrm{O} 2$ detoxifying enzymes in green and greening barley seedlings under cadmium stress. Plant Sci. 2001, 160, 1085-1093. [CrossRef]

45. Ji, X.; Liu, S.; Huang, J.; Bocharnikova, E.; Matichenkov, V. Monosilicic acid potential in phytoremediation of the contaminated areas. Chemosphere 2016, 157, 132-136. [CrossRef]

46. Kanwal, U. Potential of Alternanthera Bettzickiana (Regel) G. Nicholson For Remediation of Cadmium-Contaminated Soil Using Citric Acid. Pak. J. Agric. Sci. 2019, 56. [CrossRef]

47. Varun, M.; D'Souza, R.; Pratas, J.; Paul, M.S. Metal contamination of soils and plants associated with the glass industry in North Central India: Prospects of phytoremediation. Environ. Sci. Pollut. Res. 2012, 19, 269-281. [CrossRef]

48. Apel, K.; Hirt, H. Reactive oxygen species: Metabolism, oxidative stress, and signal transduction. Annu. Rev. Plant Biol. 2004, 55, 373-399. [CrossRef] [PubMed]

49. Ahmad, R.; Ali, S.; Rizwan, M.; Dawood, M.; Farid, M.; Hussain, A.; Wijaya, L.; Alyemeni, M.N.; Ahmad, P. Hydrogen sulfide alleviates chromium stress on cauliflower by restricting its uptake and enhancing antioxidative system. Physiol. Plant. 2019, 168, 289-300. [CrossRef] [PubMed]

50. Rizwan, M.; Ali, S.; Abbas, T.; Adrees, M.; Zia-Ur-Rehman, M.; Ibrahim, M.; Abbas, F.; Qayyum, M.F.; Nawaz, R. Residual effects of biochar on growth, photosynthesis and cadmium uptake in rice (Oryza sativa L.) under Cd stress with different water conditions. J. Environ. Manag. 2018, 206, 676-683. [CrossRef] [PubMed]

51. Rizwan, M.; Ali, S.; Adrees, M.; Ibrahim, M.; Tsang, D.C.; Zia-Ur-Rehman, M.; Zahir, Z.A.; Rinklebe, J.; Tack, F.M.; Ok, Y.S. A critical review on effects, tolerance mechanisms and management of cadmium in vegetables. Chemosphere 2017, 182, 90-105. [CrossRef] [PubMed]

52. Agnello, A.C.; Huguenot, D.; Van Hullebusch, E.D.; Esposito, G. Enhanced phytoremediation: A review of low molecular weight organic acids and surfactants used as amendments. Crit. Rev. Environ. Sci. Technol. 2014, 44, 2531-2576. [CrossRef]

53. Labra, M.; Gianazza, E.; Waitt, R.; Eberini, I.; Sozzi, A.; Regondi, S.; Grassi, F.; Agradi, E. Zea mays L. protein changes in response to potassium dichromate treatments. Chemosphere 2006, 62, 1234-1244. [CrossRef] 